\title{
TEMPLOS DE LA CIUDAD MEDIA: SANTUARIOS DEL GAUCHITO GIL EN ESPACIOS URBANOS DIFERENCIADOS
}

\author{
Daiana Mignogna ${ }^{1}$
}

\section{Introducción}

En este artículo nos proponemos comprender el proceso social de distinción o diferenciación social que involucra a creyentes del Gauchito Gil en santuarios urbanamente distintivos. Analizaremos etnográficamente esas espacialidades heterogéneas en las cuales se practica el culto al Gauchito Gil en una ciudad media del centro bonaerense, partiendo del siguiente supuesto: el modo en que diferentes sectores vivencian el espacio urbano y las prácticas religiosas en torno a este santo popular se estructura sobre la base de una diversidad de lo que los actores consideran sagrado y profano en cada práctica. Y el desarrollo tendrá en cuenta el espacio urbano en el cual están insertos estos templos, sus vinculaciones y distinciones en relación a los imaginarios hegemónicos de la ciudad de Olavarría.

Teniendo en cuenta la incidencia de los aspectos estructurales en los imaginarios urbanos, de acuerdo con un aspecto del objetivo general del proyecto "Antropología de ciudades medias del centro bonaerense: sistema urbano, imaginarios sociales y tramas de poder" (PIP-CONICET), nos proponemos mostrar cómo se vive la ciudad por los actores que la producen y consumen a través de una práctica de culto popular.

Para alcanzar el objetivo general del trabajo, partimos de herramientas metodológicas y analíticas propias del enfoque antropológico, las cuales nos permiten construir la otredad de los actores, analizarlos situacionalmente e identificar y analizar sus racionalidades. Nos valdremos de la perspectiva etnográfica o enfoque cualitativo el cual se esfuerza por documentar lo no documentado (Rockwell, 2009), es decir, aquello que permanece oculto o naturalizado. Las diferentes técnicas y herramientas de este enfoque o perspectiva nos permitirán alcanzar, al mismo tiempo, un extrañamiento y un acercamiento al objeto de estudio con el fin de construir una otredad conceptual, "exotizando lo cotidiano" para registrar cuáles son los significados que se ven aparejados en los discursos de los actores.

\footnotetext{
${ }^{1}$ Universidad del Centro de la Provincia de Buenos Aires, Argentina.
} 
El antropólogo experimienta [...] el extrañamiento como unidad contradictoria: al ser, al mismo tiempo, aproximación y distanciamiento [...] una tensión existente entre el antropólogo como miembro de un sistema social cognitivo intentando transformar lo exótico en familiar (Lins Ribeiro, 2004: 195).

Dentro de este enfoque se tendrá en cuenta el histórico-estructural (Singer, 1981) (Gravano, 2013) que hará posible explicar el origen social e histórico de esas prácticas y representaciones. De esta manera, se podrá mostrar e interpretar la heterogeneidad social y la "participación diferenciada de los hombres en los procesos de producción y distribución, es decir, de una sociedad de clases” (Singer, 1981: 9). Se utilizará también un enfoque significacional de lo urbano, entendiendo que son indisociables y en vinculación dialéctica, para dar cuenta - ambas dimensiones - de las contradicciones inherentes a los procesos sociales que se desarrollan en la problemática a investigar y de la tensión constante establecida entre ambas dimensiones y entre distintos sectores sociales.

Hemos realizado entrevistas en profundidad y observaciones en diferentes oratorios en los que se rinde culto al santo popular Gauchito Gil en la ciudad de Olavarría. Estos, exhiben una heterogeneidad socio-espacial asociada a cinco tipos específicos de prácticas: la del culto doméstico, la del culto de la "barrita de la esquina", la del culto rutero "decente", la del culto rutero de los "pibes chorros" y la del culto digital. En este trabajo nos ocuparemos de cuatro de estos santuarios, quedando por fuera del análisis el oratorio digital. En cada uno de los mismos realizaremos un ejercicio de tipificación para identificarlos, describirlos y analizarlos teniendo en cuenta tres aspectos principales: los valores que se esgrimen en torno a la creencia, el espacio urbano en el cual se insertan y el tipo de ofrendas que se realizan.

De esta manera, se intentará mostrar cómo la heterogeneidad en el culto cuestiona conceptualmente la supuesta homogeneidad de la ciudad que se construye socialmente desde el imaginario hegemónico urbano.

\section{La especificidad del rango medio y la reconversión de imaginarios de crisis}

La ciudad media de Olavarría está ubicada en el centro de la Provincia de Buenos Aires y es cabecera del partido homónimo cuya población alcanza poco más de 100 mil habitantes. En 1868 fue fundada como asentamiento en el marco de la expansión nacional a costa de la población indígena, en 1877 se oficializa como partido 
y como ciudad en 1908 (Gravano, 2005: 23). Sus sierras constituyen la materia prima primordial para las fábricas asentadas en sus alrededores.

Así como la ciudad capitalista ha construido el mito de la modernidad, la ciudad media (capitalista) del centro bonarense construye el mito del crisol social (ciudad "gringa" o blanca oponiéndose a los indígenas). La identidad hegemónica olavarriense se ha edificado sobre la base del olvido histórico de los indios americanos a la vez que se afirman valores vinculados con la "civilización" europea ${ }^{2}$. Las imágenes de frontera se reflejan en el imaginario erudito local y en el oficial, los blancos contra los indios (Gravano, 2005: 37).

La identidad de la ciudad se ha escalonado sobre la base de la superposición de diversas imágenes de la ciudad que han ido abonando tanto el proceso de cómo vivir el esplendor cuanto de cómo vivir la crisis hoy (Gravano, 2005: 35).

Este escalonamiento de imágenes conformaría un palimpsesto (Gravano, 2005), ninguna de ellas desaparecería sino que servirían de piso para las ulteriores.

Estas imágenes vigorosas (Lynch, 1966) de momentos de esplendor ecónomico como la modernización capitalista- que sitúan a la ciudad como un polo productivo generador de fuentes de trabajo y progreso, han sufrido procesos de reconversión en épocas de crisis donde la "ciudad del trabajo" contrasta con la del "ex-trabajo". Las políticas neo-liberales desarrolladas en la Argentina durante la década de 1990 vinculadas a la flexibilización y precarización laboral, desempleo y privatización condujeron a importantes transformaciones en la sociedad local dando lugar a una serie de procesos de fragmentación y reconversión de imaginarios ${ }^{3}$ (Boggi, 2007). La identidad Olavarriense emblematizada como "ciudad del trabajo" se quiebra por el gran índice de desocupación. La desigualdad y empobrecimiento ocasionado por el neoliberalismo se relaciona, como sostiene Pilar Monreal (2016), no sólo con la privatización y desocupación sino con

\footnotetext{
${ }^{2}$ El libro Imaginarios sociales de la ciudad media exhibe datos interesantes para entender el olvido histórico de los nativos americanos. Sólo el 2\% del total de la población de la ciudad media es extranjera, pero, el 98\% restante se considera descendiente de "gringos" antes que nativos.

${ }^{3}$ Partimos de la definición de imaginarios de Mons (1992: 25) como un sistema de imágenes y representaciones sobre el espacio de la ciudad. Resulta de suma importancia ya que actúa como mediador articulando lo estructural con lo significacional. Entendemos, además que ese imaginario urbano social se construye dinámicamente en tanto no todos los sectores viven de la misma forma ese espacio.
} 
Políticas públicas alejadas de las necesidades de la mayoría de la población y encaminadas a la privatización o desaparición de todos los servicios públicos: las necesidades de consumo de los residentes urbanos [...] han de ser garantizadas por un mercado, no por el Estado (Monreal, 2006: 103).

De este modo, la ciudad garantiza el acceso a sus consumos y servicios colectivos urbanos "sólo al que pueda pagarla" (Gravano, 2005: 21). La ciudad se convierte en mercancía, librada al juego del mercado; los accesos dependerán de voluntades individuales. Se privatiza crecientemente lo público negándose así la ciudad como un derecho para la totalidad de sus ciudadanos, "la ciudad misma troca su función universal de derecho en un brete económico de hecho, prendado por la condición de ser usada sólo por el que la pueda pagar" (Gravano, 2005: 22).

El rango intermedio no remite sólo al tamaño de su población sino que se vincula a su especificidad ligada a lo significacional, a los imaginarios propios de las historias y procesos culturales de ciudades intermedias, las cuales se caracterizan por no pertenecer a una región metropolitana pero tampoco se posicionan como centros rurales.

El imaginario que la define como una ciudad-pueblo o un pueblo-ciudad, "la "certidumbre" ante el nosotros necesario entra en crisis y se empieza a plantear extrañamientos: 'antes nos conocíamos todos [...] esto era un pueblo..."' (Leiro, 2005: 108).

En este ejercicio de extrañamiento nativo se negativiza y excluye a determinados sectores diferenciando a esos "otros" de un "nosotros", rasgo característico de las construcciones de identidad ${ }^{4}$.

La emblematización olavarriense que enarbola "hitos civilizatorios" se actualiza en procesos de segregación, estigmatización y exclusión de diferentes sectores. Hoy en un contexto de políticas neoliberales de ajuste - , ¿de quién y para quiénes es la ciudad? ¿Qué alternativas pueden producir los sectores subalternos productores materiales de la ciudad? ¿De qué manera atraviesa o interviene la imagen emblemática "ciudad del trabajo" en las luchas de sentido entre los diferentes "templos" y entre estos y la ciudad? ¿Cómo viven la religiosidad -inmiscuida en la cotidianidad - los grupos encargados de producir y reproducir materialmente el sistema urbano?

\footnotetext{
4 "La aparente incapacidad de constituirse en sí sin excluir al otro y la aparente incapacidad de excluir al otro sin desvalorizarlo" (Castoriadis, 1983: 26).
} 
Intentaremos responder a algunos de estos interrogantes que comprenden la relación entre estas prácticas de culto populares y la diferenciación espacial. "Los imaginarios encarnados en prácticas protagónicas de los actores [...] mostrarán cómo viven la ciudad, además de vivir en ella" (Gravano, 2005: 25). Para esto, recurrimos al abordaje de lo urbano como "sistema de sistemas" en el que se conjugan tanto la dimensión estructural - definida como el resultado de las posibilidades materiales de desarrollo - cuanto imaginaria -las significaciones con que los actores viven esas condiciones (Gravano, 2015).

\section{Religiosidad de la vida cotidiana: el mito en el rito}

Mientras los fieles verbalizan su significación del mito sobre los sentidos en torno a la cotidianidad del gaucho llamado Antonio Gil, un color predomina simbolizando la reivindicación de su trágica muerte, característica de un héroe, un mártir o un santo a quien han degollado poco después de sujetarlo de un árbol (por medio de una soga) con su rostro contemplando el piso. Los relatos afirman que Gil no sólo no opuso resistencia sino que además solicitó al Sargento Giménez que le dieran muerte con su propio cuchillo luego de que lo escuchase con atención, ya que tenía algo muy importante que narrarle: cuando llegase a su casa se encontraría con su más pequeño hijo enfermo y éste sólo se salvaría si volviese a ese lugar y le diera un entierro digno. Ocurrió así el primer gran milagro posterior a su muerte, pero no el único. Ya en su vida cotidiana era reconocido como el "gaucho milagrero", quien, además de luchar obligadamente contra el ejército paraguayo en la guerra contra el Paraguay, curaba a los enfermos y soldados caídos. Esta "obra de bien” practicada por Gil fue interrumpida al vivenciar un llamado de fe de un dios guaraní llamado Ñandeyra quien ordena el cese de derramamiento de sangre de inocentes hermanos. Un llamado a la reflexión sobre la contradicción de, por un lado dar muerte a hermanos y por el otro, curarlos. Es aquí que Gil escapa y es considerado desertor. Poco tiempo después, llega su "merecido" en manos de un verdugo que, paradójicamente, se convierte en su primer devoto y se encarga de divulgar lo ocurrido.

Los creyentes, a través de su construcción mítica, le atribuyen al Gauchito Gil la cualidad de ladrón noble, que constituiría una respuesta simbólica en defensa de los abusos de poder (Míguez, 2008). Reivindican la figura de "justiciero" y lo comparan 
con "Robin Hood" en el hecho de "robarle a los ricos para darle a los pobres". La historia que narran caracteriza a un héroe, mártir y santo a quien han degollado por alzarse contra el orden establecido y desafiarlo. El Gauchito Gil encarnaría entonces la figura de "bandolero social" (Hobsbawn, 1983), que ha vivido al margen de la ley y que ha incurrido en situaciones de violencia y crimen, pero "en legítima defensa o para hacer justicia".

Esta narrativa se vincula a experiencias de sufrimiento - que motraremos etnográficamente - propios de esos sectores populares, quienes forman parte de los grupos segregados de la ciudad, es decir que tienen restringido el acceso a los consumos colectivos que forman el sistema urbano. Algunos autores denominan a este fenómeno como religiosidad popular (Carrozzi, 2005; Dri, 2003; Semán, 2001); forma de reivindicación e identificación de sectores atravesados por políticas neoliberales de los años 1990 y 2001 que los arrojaron a la pobreza extrema. Constituye una fuerza de resistencia en la que el ingenio popular se sobrepone a las carencias y se burla corrosivamente del poder. Podría connotar una forma de protesta social o expresar otro orden moral que difiere del hegemónico (Carrozzi, 2004; Míguez, 2008).

La práctica de culto al Gauchito Gil les permite vivir, hacer, actuar la ciudad a pesar de su condición desigual. Un flujo mítico como el del Gauchito Gil actúa como solución a contradicciones estructurales expresadas en el imaginario de "la ciudad del trabajo" (y del "ex-trabajo", durante la crisis de fin de siglo). Entendemos al mito como un conjunto de "imágenes asociadas a la ciudad [...] que funcionan como deshistorizadores y a la vez condicionantes de prácticas sociales" (Gravano, 2005: 46). El mito a este santo popular posibilita a los fieles encabezar un rito que no sólo se articula a la práctica específica de intercambio y dones, pedidos y ofrendas, sino que atraviesa la vida cotidiana de los fieles. La religiosidad no se reduce al altar, se imbrica en la cotidianidad constituyendo maneras de actuar, vivir y sentir la ciudad. A su vez, las representaciones hegemónicas que el resto de la ciudad posee de ellos se manifiesta también en la práctica de culto y creencia. Los mapas imaginarios de la ciudad media se proyectan al interior de espacios institucionales, consumos culturales y grupos religiosos (Boggi, Leiro, Caffarelli, Zamora, 2005) evidenciando "quiénes son dignos (y necesarios) y quiénes no para ostentar su pertenencia a ella, dando, al mismo tiempo, origen y justificación a los mecanismos de exclusión” (Boggi, 2005: 132). 
Estos templos urbanos en los cuales se rinde culto al Gauchito Gil, están ubicados en vías de acceso a la ciudad y en el interior de barrios periféricos, es decir, de aquellos "barrios mancha" que "aparecen en el imaginario urbano de Olavarría mediante la estigmatización de ciertos barrios de vivienda social, creados a partir de la cobertura estatal de ese consumo" (Gravano, 2005: 90) y que los imaginarios mediáticos y hegemónicos construyen como "peligrosos", "llenos de delincuentes" y "vicio". La imagen de ciudad de frontera definida desde lo dominante como "fortines" e "hitos civilizatorios" se actualiza en procesos de segregación, estigmatización y exclusión de diferentes sectores. "Ayer los indios, hoy esos barrios" (Gravano, 2005: 49).

\section{Tipificaciones de los templos urbanos}

Como señalamos, realizamos una tarea metodológica de tipificación de diferentes espacios de culto con el objetivo de clasificar y ordenar nuestro objeto a fines de construir conocimiento. Respecto de los santuarios "ruteros", decidimos diferenciarlos a partir de la tipificación "el de los pibes chorros" y "el de la gente decente". Los que se autoadscriben dentro de este último, caracterizan a los "otros" como "los chorros". Esta estrategia analítica de las Ciencias Sociales que como sostiene Rosana Guber nos brinda la posibilidad de clasificar lo que nos rodea agrupando individuos, cosas o situaciones a partir de la homogeneización de rasgos que se consideran significativos, tiene estrecha relación con representaciones e imaginarios del sentido común 5 .

Las tipificaciones obran con un sentido político - en el sentido común- que ubica en el lugar de la subordinación a ciertos conjuntos sociales, y que ayuda a que la población en general preste un eco favorable a medidas antipopulares y violentas para con estos sectores (Guber, 2013: 131).

\footnotetext{
${ }^{5}$ Conjunto de valores e ideas que nos resultan "naturales", que no necesitamos someter a prueba, los que utilizamos cotidianamente.
} 


\section{Los santuarios "ruteros"}

Estos espacios de culto, en general, se caracterizan - artísticamente - por su espontaneidad y practicidad. Constituyen lugares "de paso" cuya función principal reside en brindar protección al viajante. Entre sus hacedores se encuentran los camioneros quienes a modo de ofrenda construyen altares a la vera de las rutas con el objetivo de obtener protección durante sus viajes de trabajo.

Yo cada vez que puedo paro, le dejo algo que tenga y sigo. Cuando tengo más tiempo le hago un santuario yo con madera o lo que tenga a mano y una velita y una estatuita. La mayoría de estos que ves en la ruta lo hacemo nosotro (trabajador del transporte, 35 años).

Otros fieles realizan un oratorio dedicado al Gauchito Gil en las rutas por motivo de cercanía a su vivienda o porque consideran que es necesario hacerlo visible, también constituye un lugar de reunión y socialización reservado para los fines de semana,

Acá venimos los domingos generalmente, somos todos conocidos viste. Venimos a pasar un buen rato, charlar, tomar mates, comer algo compartiendo con nuestro santo (hombre, 60 años, creador de un santuario rutero).

Los santuarios ruteros objeto de análisis, al igual que tantos otros, captan nuestra atención al transitar por sus cercanías. Se ubican a la vera de accesos a la ciudad, un color con historia predomina intenso, generando opiniones controversiales e invitando a los transeúntes. Podemos contemplarlos desde la ruta, acercarnos al predio o presionar la bocina a modo de saludo en caso de que permanezcamos en un vehículo. Aunque tengamos desconocimiento del fenómeno, podemos intuir de qué se trata pues su presencia denota un cierto sistema de signos que nos comunica su especificidad religiosa. Predomina lo artesanal entremezclado con estatuillas e insignias del catolicismo. Estampitas, estatuillas, cruces y velas se combinan con bebidas alcohólicas, cigarrillos, fotos con pedidos, atuendos y otros objetos donados por fieles. El análisis de los símbolos rituales podría indicar una diferenciación social. Los dones que los fieles otorgan a su santo popular -además de que como condición deben poseer carácter de sacrificio o "algo que cueste dar"- tienen estrecha relación con sus prácticas cotidianas, porque de alguna forma los representa. Simbolizan prácticas cotidianas, modos de actuar y de vivir la ciudad. Por este motivo, creemos necesario focalizar en las ofrendas 
que en los diferentes santuarios tienen ciertos significados y que además, permanecen en relación dinámica con diferentes valores predominantes en el culto.

\section{Santuario de "la gente decente"}

Érase un día soleado del mes de abril. Estaba en presencia del síndrome de la "utopía holística" (Boggi, 2007: 23), esforzándome por permanecer en alerta constante, ampliar la mirada y registrar todo lo que se desplegaba ante mis sentidos. Afortunadamente, en el espacio de culto, había unas cinco personas adultas sentadas en bancos de cemento - contiguos al altar - compartiendo mates, risas y charlas bajo el aire de los árboles. Las miradas se volvieron hacia mí, saludé, respondieron atentamente. Observé el lugar y comencé a tomar nota, con temor - confieso - a que algo se me escapara.

El espacio de culto público se ubica en las inmediaciones de los barrios Isaura y Eucaliptus ubicados ideológicamente como "los atrases" de la ciudad (Gravano, 2005: 84). Escasas calles permanecen pavimentadas, la mayoría es de tierra y con inmensos pozos que dificultan el tránsito, aún más cuando abundan las precipitaciones. Las viviendas denotan signos de autoconstrucción y pueden ser consideradas "chacras" o "viviendas rurales" por muchos de los habitantes de la ciudad a causa de la cría de ganado porcino, de aves (gallinas y patos), entre otros. Los hogares parecen estar construidos con lo "que se tiene o se puede conseguir", es decir, son precarios, bloques a la vista, la mayoría sin terminar. En los techos, se pueden divisar chapas sueltas que realizan fuertes sonidos cuando sopla el viento. Los niños corren, juegan, se pelean y pasean en bicicleta. Los días soleados también los adultos salen de sus viviendas y comparten mates a la sombra de algún árbol. Estos barrios, aparecen como "unos de los más nuevos de Olavarría". En reiteradas ocasiones, titulares de los diarios notifican sobre los arduos reclamos de vecinos que intervienen los espacios en la lucha de consumos y servicios colectivos urbanos los cuales no le son garantizados (gas natural, pavimento, viviendas, alumbrado público). 


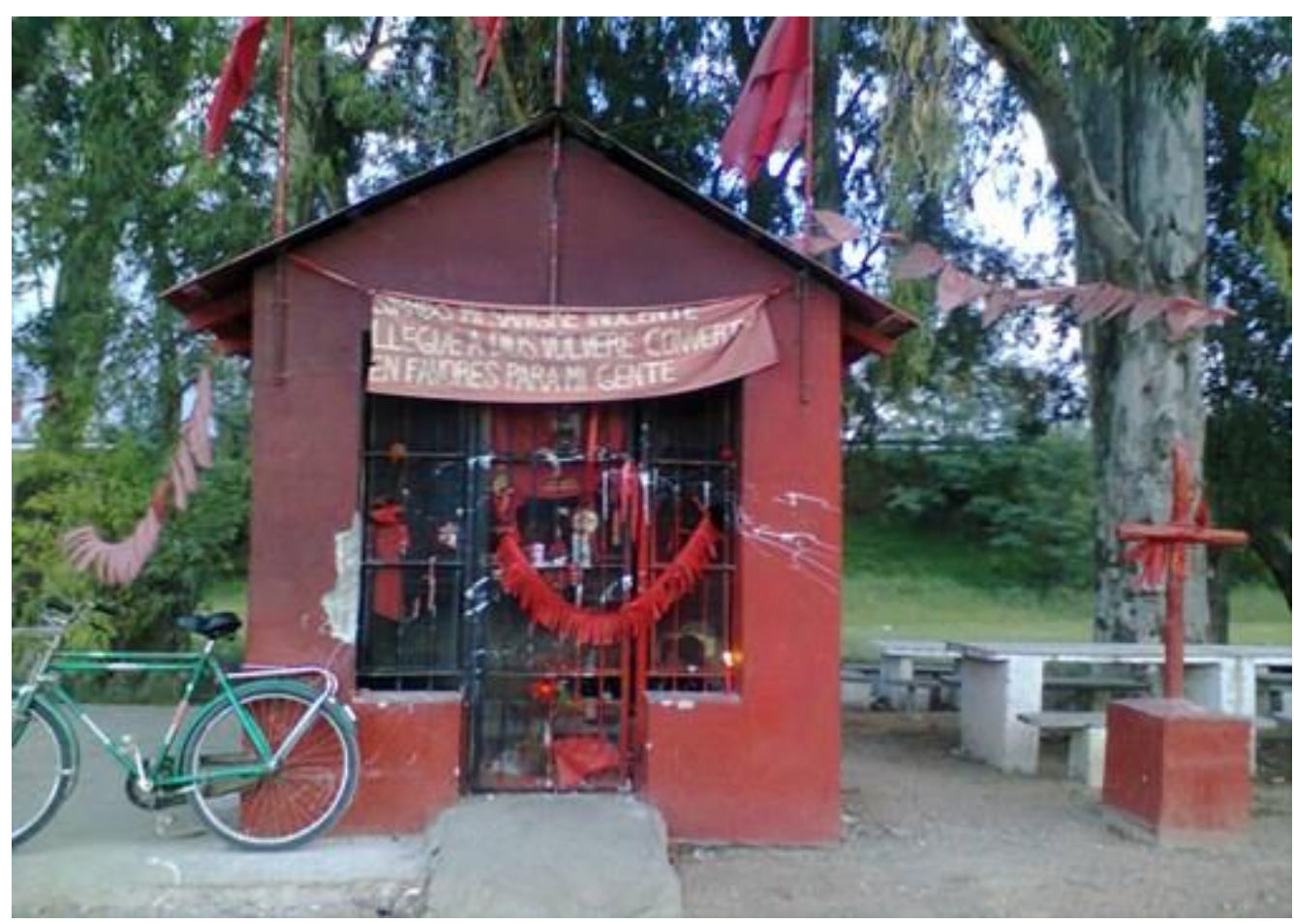

Santuario “decente”, ubicado debajo del puente de la ruta 226 y la avenida Junín.

El altar está situado debajo del puente de la ruta 226 sobre una calle carente de asfalto. Unos cuantos árboles invitan a descansar bajo su sombra. Las mesas - pude contar siete - permanecen ubicadas estratégicamente: debajo de los árboles. Seis de ellas, pueden amparar a cuatro personas y la restante realizada a modo de tablón, albergaría al doble. Las mesas permanecen fijas al piso, construidas a base de cemento. El lugar, también cuenta con parrillas. El paisaje a la redonda se asimila a la ciudad, no por la cantidad de viviendas, sino por la presencia de botellas, bolsas, papeles, cajas tiradas.

Junto a los bancos, llama la atención el imponente altar, construido de material y pintado de color rojo simulando una pequeña "casita" de aproximadamente dos metros de ancho y largo. Es decir, altar cuadrado en la base para terminar de manera triangular en la parte superior. La puerta está hecha de hierro pintado de rojo conformando una reja que durante el día permanece abierta. Su interior presenta infinidad de ofrendas. Velas rojas y blancas, santos y vírgenes católicas, botellas de vino, cigarrillos, cartas, fotos, rosarios, cuadros, mates, estatuillas, rosarios, estampitas, flores de plástico, cintas, guirnaldas rojas, cigarrillos. También cartas y carteles de agradecimiento: "Gracias Gauchito Gil por escuchar a mi nietito". En el piso hay ofrendas caídas cubiertas en gran parte por tierra. Se pueden observar, zapatitos de bebé, banderas rojas, adornos del 
Gauchito Gil, fotos, una taza del Gauchito y San la Muerte juntos, una botella grande con un papel escrito dentro y un prendedor de Antonio Gil.

Los días de cortejo al santo - que coinciden con el descanso laboral de muchos fieles- suelen ser los fines de semana, más aún los días domingo. Generalmente los fieles que visitan este santuario son personas adultas de entre 40 y 70 años - la presencia de jóvenes es notoriamente escasa - quienes disfrutan de la oportunidad de pasar el día en familia. Algunos de los hombres que asisten suelen vestirse con un estilo notoriamente "gauchesco" 6 otros con camisa, chomba o remera, jean o pantalón de vestir y zapatillas deportivas. La vestimenta parece cumplir los requisitos de "dominguera", es decir, limpia, planchada y "arreglada" aunque denota varias posturas o usos. Varias mujeres con polleras largas y blusas, pantalones livianos y calzado estilo "guillermina" $"$. El estado de la indumentaria femenina es similar a la masculina, pulcra y sin arrugas pero usada varias veces. En su mayoría, los asistentes llegan al lugar en vehículos, autos antiguos y nuevos, camionetas pick ups y alguna combi.

En conmemoración de la muerte de Antonio Gil, los 8 de enero, en todo el país, los fieles que carecen de la oportunidad de dirigirse al "santuario oficial" de Mercedes, Corrientes, se reúnen en el altar que los acompaña durante el año - como es el caso del presente santuario. Rinden cortejo a su santo llevando a cabo diversas actividades recreativas, las cuales incluyen bailes y cantos como el chamamé, el folklore y también comida a la canasta. Comparten la fiesta desde la mañana hasta la noche, agasajando a su compañero sagrado que les cumple "favores y milagros".

Conversando con las personas allí presentes, conocí el motivo por el cual el santuario fue construido en ese espacio.

No vivimos cerca de aquí, pero el lugar me lo cedió Helios Eseverri (ex intendente) y lo bendijo un cura que vino de Corrientes, yo estaba muy agradecido ya que la Iglesia no lo considera santo pero igualmente bendijo el lugar (Referente del santuario y creador del mismo).

\footnotetext{
${ }^{6}$ Nos referimos a lo que se conoce como vestimenta típica de los gauchos pero un tanto modernizada o adaptada, con menos atuendos. Bombachas de campo, camisa, pañuelo en el cuello, alpargatas o botas, sombrero, poncho en algunos casos y fajas.

${ }^{7}$ Calzado sin taco, suela muy delgada y bien ajustada al pie. Tienen un estilo similar a lo que usan las bailarinas de ballets.
} 
La presencia aquí me develó la existencia de otro altar rutero. Los fieles lo nombraron de manera recurrente y negativa. "Nosotros somos los creyentes, allá hay otro santuario pero son todos pibes... chorros". Allí me dirigiría al domingo siguiente. Feriado que representa y consiste en compartir el día con "el gaucho" y en familia. De esta manera, haría propio el plan de los fieles y comenzaría a reservar los domingos para la realización de trabajo etnográfico.

\section{Santuario de "los pibes chorros" o de la no gente "como la gente"}

Se ubica en la Av. Dante Torcuato Emiliozzi justo en la curva que se dirige hacia la localidad de Sierra $\mathrm{Chica}^{8}$. En sus inmediaciones, no encontramos viviendas, sino algunas pocas y "rurales", pero no tan cercanas sino más bien adyacentes al autódromo. Está más próximo a la localidad de Sierra Chica que a la ciudad cabecera de Olavarría. El lugar es amplio. Si nos ubicamos delante, vemos, a la izquierda, la presencia de un santuario rojo. A la derecha y más alejado, una vitrina con la estatua blanca de una virgen. Entre ésta y el santuario, un letrero que anuncia la presencia de "San Expedito"9. Recorro el lugar, contiguo al santuario del Gauchito Gil, se puede visualizar un pequeño hueco en las piedras pintadas de negro. Hacia el interior, una estatuilla de San la Muerte, fotos, caña de durazno, velas negras y estampita del santo.

El santuario del Gauchito está construido a partir de cemento, su tamaño es de dos metros cuadrados aproximadamente. En el frente posee una reja cerrada que parecería abrirse fácilmente a causa de su precaria atadura de plástico. A diferencia del anterior, no se puede ingresar, ya que posee un pie de cemento y encima de éste la estructura roja donde se depositan las ofrendas. En su costado izquierdo, visible a la ruta, flamea una bandera de gran tamaño en la cual se pueden ver dos figuras: El Gauchito Gil y San la Muerte ${ }^{10}$. El altar es de color rojo, a un costado hay una cruz pintada del mismo tono en la cual cuelga una bandera - también roja - lisa. En el medio, sobre un cable visualizamos infinidad de cintas rojas y asimismo en dos

\footnotetext{
${ }^{8}$ Localidad perteneciente al partido de Olavarría, a unos 12 kilómetros de la ciudad cabecera. Posee alrededor de 5 mil habitantes. En ella subyacen tres cárceles de hombres. Una de máxima seguridad, otra de mediana y otra de mínima seguridad.

${ }^{9}$ Santificado por la Iglesia Católica y caracterizado como el "patrono de las cosas justas y urgentes".

${ }^{10}$ Santo popular al cual Antonio Gil le rendía culto. No todos los creyentes del Gauchito Gil practican el culto a este santo ya que lo consideran "menos permisivo", "más estricto con las ofrendas y cumplidos" y "más peligroso". En cambio, la mayoría de los creyentes de San La Muerte le rinden culto al Gauchito Gil.
} 
arbolitos contiguos. Delante del santuario hay un estante de chapa con el fin de que los fieles depositen sus velas. En la reja hay flores rojas colgadas y por dentro: una caja de vino marca Toro (de bajo precio), una botella, un ramo de rosas rojas, un ramo de claveles rojos, en primer plano una remera doblada con una estampa del Gauchito, la cual tiene varias firmas y escritos, entre ellos se pueden ver: "Protejenos, cuidame, ayudame" "Gracias por todo, Horacio". También hay pulseras, colitas rojas para el pelo, una gran estatua del Gauchito en el medio, otras dos pequeñas, imágenes y estampitas de Antonio Gil, cigarrillos, colillas de cigarrillos, hojas escritas, velas, zapatillas de nene o nena gastadas. Estas ofrendas están acomodadas, ordenadas y parecería que están hace tiempo, como es el caso de las zapatillas.

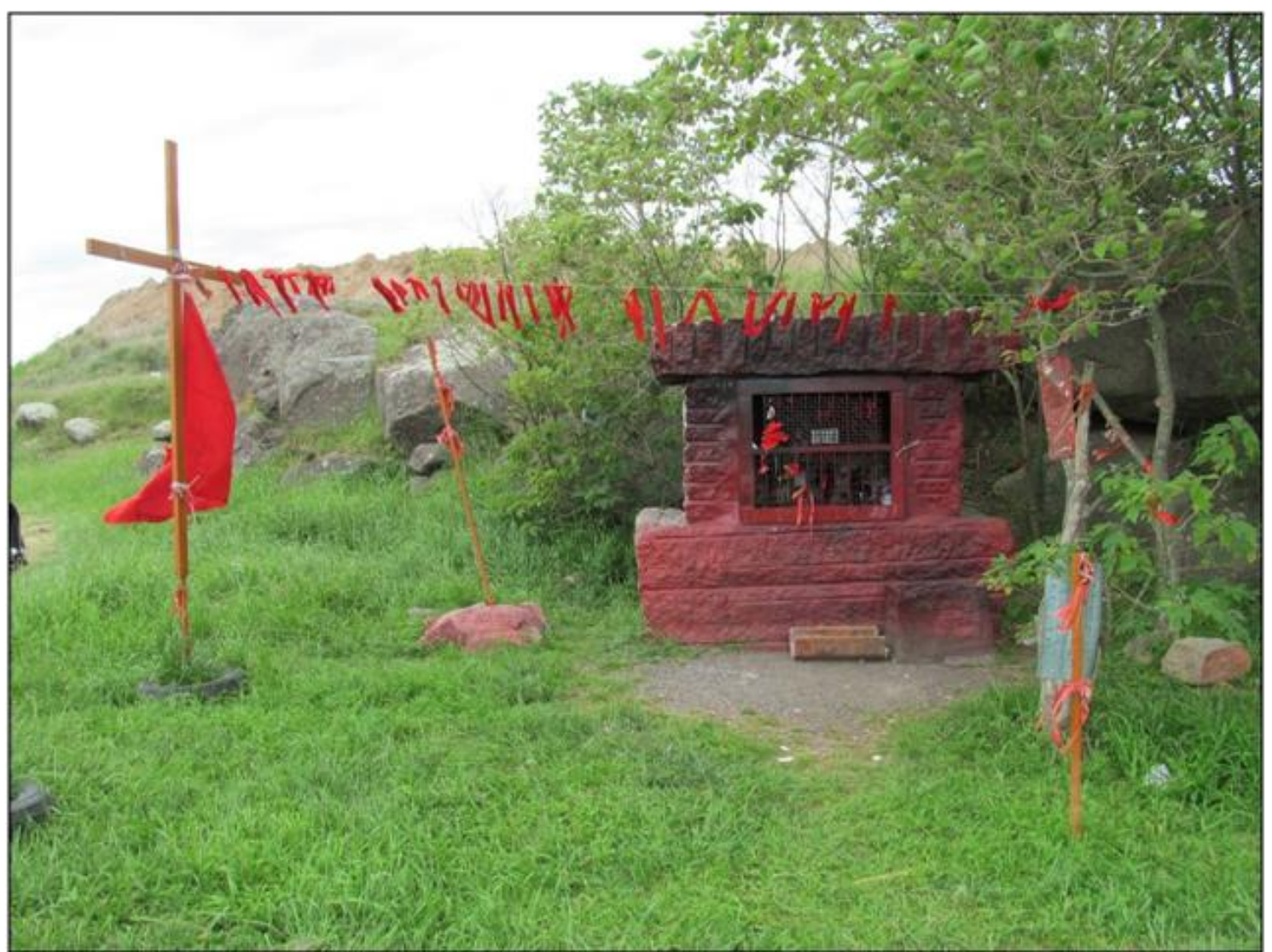

Santuario de los "pibes chorros" ubicado en la Av. D. T. Emiliozzi y la curva que se dirige a la localidad de Sierra Chica.

Detrás del altar existe un espacio entre este y una elevación serrana. Allí yacen botellas, una de vino y otra de Dr. Lemonn, otras de jugo y cerveza. Hay un santo en una bolsa, roto, parece ser San Expedito. Hay diversas hojas fotocopiadas. Tomé "prestada" una. Todas contienen el mismo escrito, una oración al santo, una imagen de éste y una solicitud: quien la encuentre debe realizar una "cadena" de diez copias más. 
También hay un termo, una caja de vino, una lata de pintura roja. Mientras tomo nota de lo que me rodea transitan autos por la carretera, muchos de éstos tocan bocina tres veces a modo de saludo. Los fieles coinciden en que se debe saludar al santo con tres bocinazos para obtener un viaje grato.

Los vehículos permanecen alejados, más cerca de las otras imágenes católicas. Las personas permanecen afuera y al lado de sus vehículos compartiendo mates, consideraría que no están allí por el santuario del Gauchito Gil, sino a modo de recreación o visita a las otras imágenes situadas en el predio.

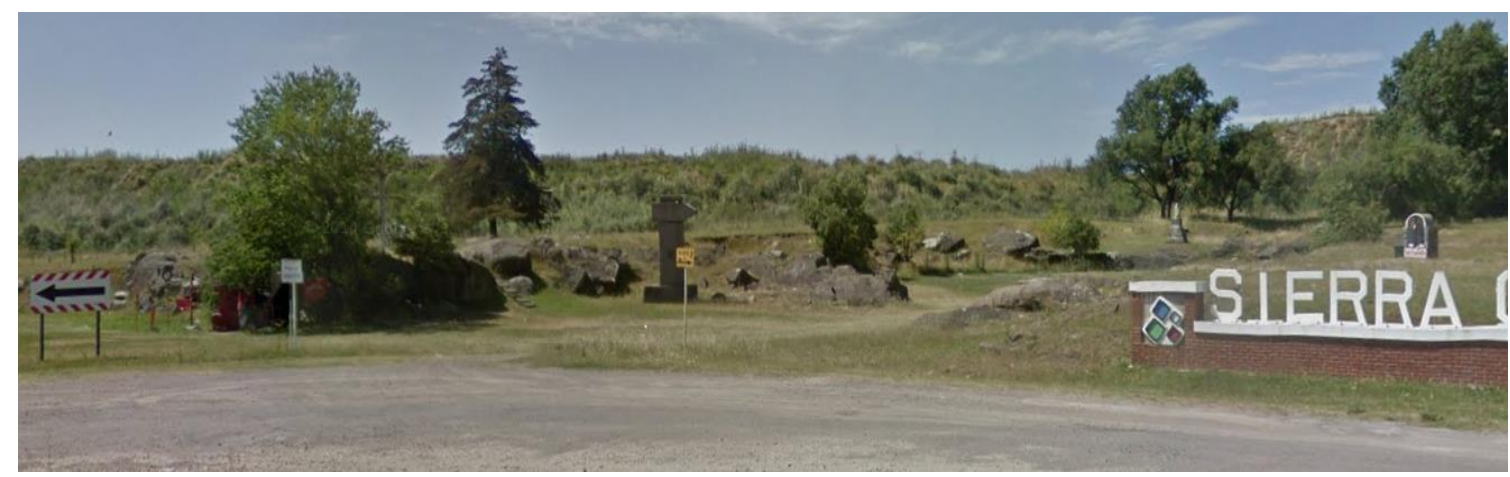

Hacia la derecha de la imagen puede notarse la imagen de la Virgen María y hacia la izquierda el altar del Gauchito.

Caminé alrededor, detrás del santuario del Gauchito Gil, y a la vuelta. Visualicé presencia de residuos como bolsas, botellas y papeles tirados. Luego, decidí subir por la pendiente utilizando una escalerita de piedras para visualizar el lugar desde otra perspectiva o panorama. Pude observar a dos jóvenes que se retiraban en moto. Un muchacho vestido con un buzo amplio, un pantalón deportivo y zapatillas deportivas junto a una chica con un buzo blanco, un jean y zapatillas deportivas, ambos tendrían aproximadamente 25 años. Como este ejemplo, la mayoría de fieles que se acercan a pasar un momento con "su santo", llegan en moto. Son en su mayoría jóvenes de entre 15 y 30 años, algunos permanecen sólo un momento, otros comparten alguna bebida como el vino y algún cigarrillo de marihuana; la "tuca" ofrendada al "gaucho". Algunos de los asistentes se encuentran en estado de precarización laboral, desocupación o en situación de ilegalidad laboral. Mencionan realizar "changas" para mantener a su familia o "rebuscarselas como sea". Cuando se les pregunta por el lugar en el cual viven o por "su" barrio, las respuestas oscilan entre:

\footnotetext{
${ }^{11}$ Sobrante del cigarrillo de marihuana. La parte inicial, por donde se pita.
} 
Sarmiento, Sarmiento Norte, “104”, Independencia, Nicolás Avellaneda, Isaura, Mataderos, y "Escuela 6". Otros de los jóvenes que concurren, viven en la localidad cercana de Sierra Chica o, no viven específicamente en la ciudad pero mencionan acercarse al santo con el motivo de solicitar la"libertad de los pibes y familiares" detenidos en Sierra Chica.

\section{EI santuario "de la esquina" o "de la barrita de la esquina"}

Según vecinos y fuentes documentales del imaginario erudito olavarriense, el santuario se ubica el interior de un barrio de vivienda social autoconstruido por cooperativas con apoyo estatal de una ciudad media como alternativa a la crisis social nacional que afectó a vastos sectores de la sociedad. Las características generales de las viviendas son similares a la otro de los barrios periféricos de la ciudad de Olavarría descripto por Gravano “de una planta, de construcción económica, de delgadas paredes y medianeras, con patios que actuarían como escenarios de relaciones entre los vecinos" (Gravano, 2005: 91).

Antes de dirigirme al espacio de culto, recorrí algunas calles del barrio para conocerlo. En las veredas vecinos conversando, gente sentada en sillas tomando mate, otros lavando sus vehículos, niños jugando, portones, ventanas y puertas abiertas. Algunas casas con sus paredes rotas, desmoronadas; por fuera, basura alrededor, juguetes rotos y con apariencia añeja, en el piso, colchones, fierros, madera, pañales, entre otras cosas. Viviendas a medio construir contrastan con chalets culminados de colores vívidos y con detalles de molduras, piedras, ladrillos. Calles de tierra y calles de asfalto. Vehículos nuevos y costosos en perfectas condiciones de chapa y pintura a la vez que podía visualizar vehículos antiguos, abollados, sin pintura, oxidados, algunos parados sin funcionar. Algunas de las calles con abundante presencia de basura en los laterales. Con respecto a la música, el barrio es representado a través de la cumbia que se oye fuerte y en diversas viviendas y calles, mezclada con cantos y gritos de niños, también con retos hacia éstos por parte de algunos familiares.

Cuando me acerco al santuario, observo dos jóvenes de no más de treinta años. Uno de ellos jalando de una soga amarrada a un auto de juguete de un metro aproximadamente. Allí dentro, un niño de un año. Este joven lucía una gorra negra con la visera hacia atrás, una remera manga corta de un equipo de fútbol, bermuda deportiva 
y zapatillas deportivas color azul. Su compañero, una remera de Racing de Olavarría, comúnmente conocido como "El Chaira" y un pantalón corto deportivo de color negro, sus zapatillas también deportivas de color amarillo. La vestimenta con aspecto cuidado y nuevo. Luego de unos minutos se acercan dos niños más, uno con una remera de River y una gorra visera, de aproximadamente seis años y otro pequeño de no más de tres.

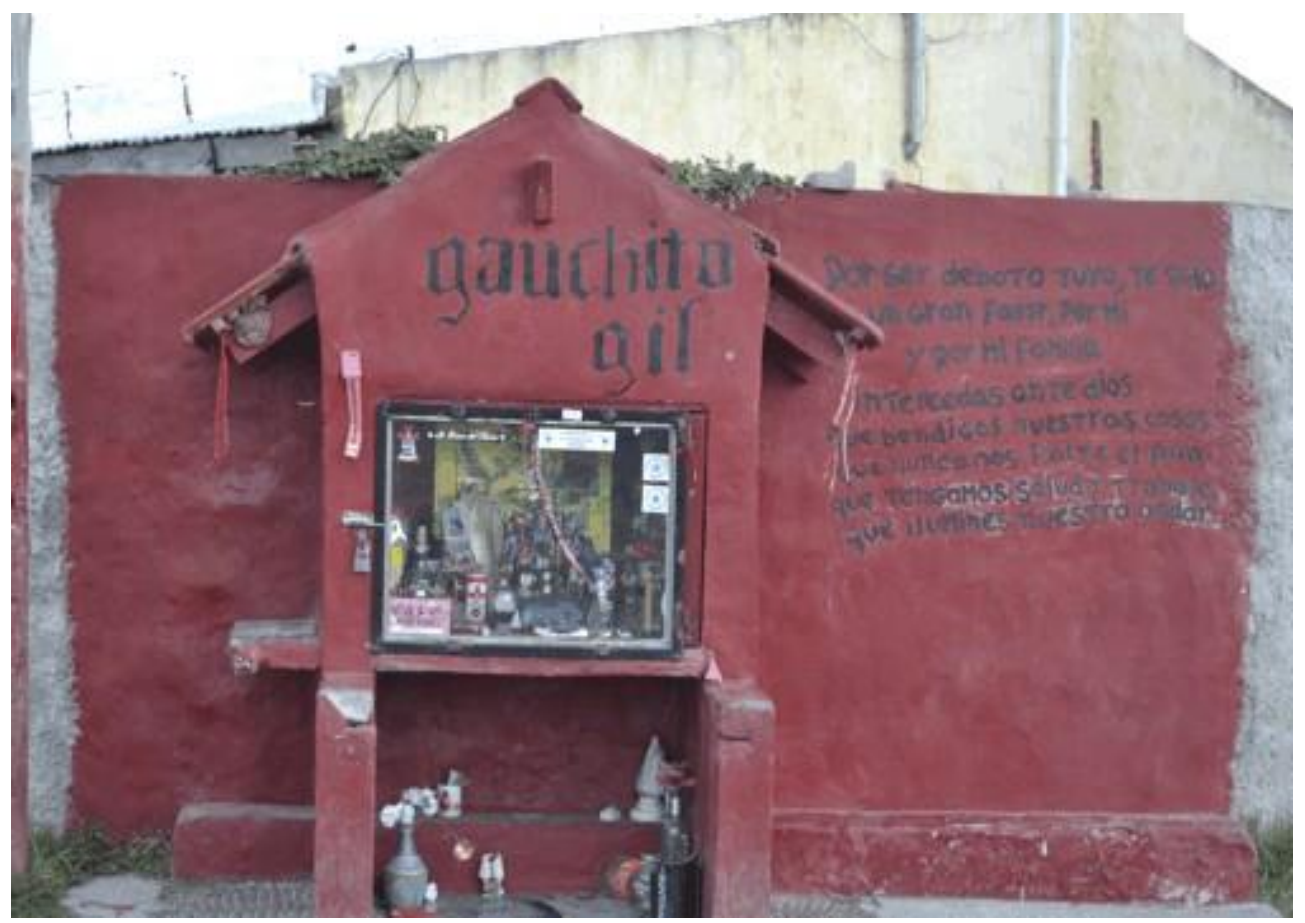

Las visitas a este santuario dejaron ver la recurrencia de jóvenes del sexo masculino sentados en la esquina del santuario. La "barrita de la esquina", está conformada por aproximadamente diez jóvenes que permanecen allí desde que cae el sol hasta la madrugada. Identifican a ese espacio como "el lugar de ranchada con los pibes $^{12}$. Comparten cervezas, vino, marihuana y tabaco. Ellos sostienen que van allí a compartir con el gaucho, le prenden velas y le ofrendan dones. Mencionan cuidar del oratorio ya que para los vecinos del barrio este espacio no es de agrado por el motivo de que "junta vagos".

Este espacio es visible desde otros puntos del barrio, podría decirse que su ubicación es estratégica. Permanece al frente de la casa del "líder de la barrita" y constructor del santuario. Su estructura está realizada a base de cemento pintado de

\footnotetext{
${ }^{12}$ Esta es la manera que poseen los jóvenes entrevistados de caracterizar las reuniones con amigos, compartiendo por ejemplo cerveza, vino y marihuana, entre otras cosas.
} 
color rojo. La puerta es de vidrio. Cuando ellos están allí, permanece abierta, sino cerrada con un candado. Sobre el vidrio se pueden visualizar calcomanías de "el Chaira" ${ }^{13}$. En su interior hay balas, papelillos, estatuas, rosarios, fotos, patentes, estampitas, tucas, dinero, velas, vino, armas (calibre 38 e itacas), entre otras.

\section{Santuario doméstico}

Andando en bicicleta por la calle que recorre a lo largo el club "Chaira" me alegra el saber que en unas cuadras dejaré de luchar contra el viento y me encontraré con Naty, Dani y su hija Azul. Dos jóvenes con historias similares que se conocieron en la adolescencia y continúan hoy, viviendo juntos en el barrio "Sarmiento Norte". Alan es un chico delgado y de estatura mediana, cumplió 20 años hace poco tiempo. Suele vestirse con camisetas de fútbol y pantalones deportivos anchos. Utiliza, a veces, palabras y expresiones que desconozco y habla en tono bajo pero rapidito. Podría tanto afirmar que "es de pocas palabras" como que conversa "bastante" ya que depende de las personas que estén a su alrededor. Alan vivió en el barrio desde chico, al igual que sus hermanos y hermanas. Desde su adolescencia ejerce prácticas ilegales (como el robo) junto a su tío para "no hacerle faltarle nada a Naty y Azul"; mientras que Naty desarrolla las tareas domésticas y el cuidado de Azul. Él pasa la mayor parte del día fuera de la vivienda visitando amigos - algunas veces los amigos lo visitan a él - y haciéndose su propia vivienda junto a albañiles amigos. De noche regresa tarde, en la madrugada, luego de trabajar $^{14}$.

Yo rastrero no soy, no le voy a robar a un pobre loco, pero bueno también vite que están los que te dicen robale a la gente de guita guita y ¿qué te pensá? ¿que es fácil?, esos están re zarpados en vigilancia.

Consume marihuana y cocaína y por ésta última se generan discusiones con Naty (quien no consume). Ella pasa la mayor parte del día en su hogar, de vez en cuando recibe visitas de alguna amiga - pero pocas veces por lo que comenta. Naty tiene

\footnotetext{
${ }^{13}$ Racing Atletic Club es un club deportivo ubicado en Olavarría, ciudad del interior de la Provincia de Buenos Aires. En el mismo, se practican distintas disciplinas como: fútbol, básquet, sóftbol, boxeo y taekwondo. El equipo de fútbol, apodado "el chaira" y "la estrellita", compite actualmente en el Federal B, división que corresponde a la cuarta categoría del fútbol argentino, y también en la Liga de Fútbol de Olavarría. La identidad de este club tiene directa vinculación con el club Estudiantes, se los conoce como rivales. Los "Chairas" lo identifican como el club careta o de los caretas sin hinchada sin aguante y ellos a los Chaira como pobres, negros quilomberos, entre otros.

${ }^{14}$ De esta manera Alan identifica a la práctica ilegal por la cual abastece a su familia de lo necesario para vivir.
} 
21 años, es de estatura mediana, suele vestirse con ropa al cuerpo, habla en tono más bien bajo y pausado. Ambos son creyentes del Gauchito Gil y lo llevan tatuado en su cuerpo, Alan en la pierna, en el gemelo y Naty en un brazo. No son los únicos tatuajes que poseen, llevan también, entre otros, el nombre de su hija.

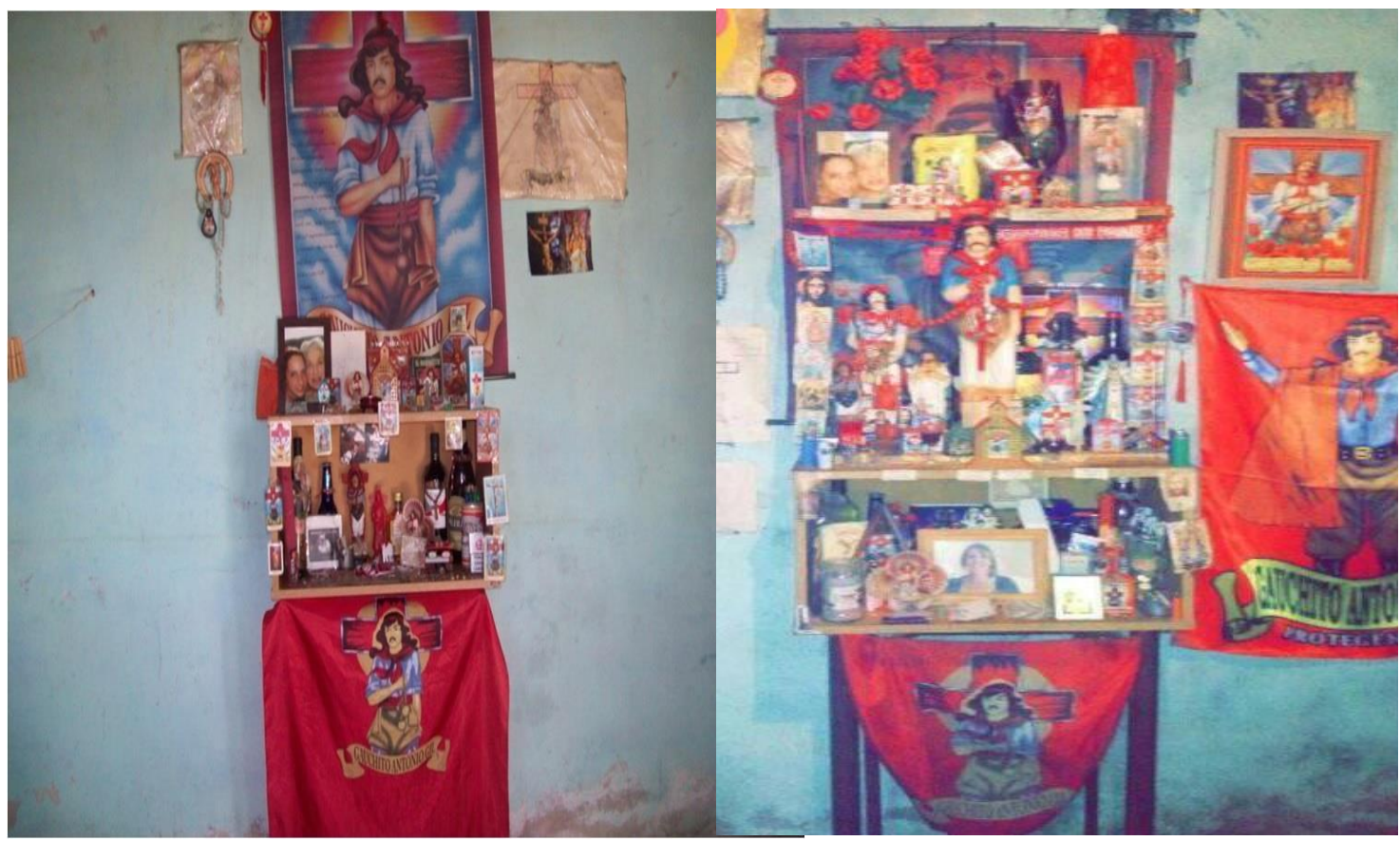

Santuario doméstico. La de la izquierda fue tomada el año 2014 y la de la derecha fue extraída este año de una red social del dueño del santuario.

Van periódicamente, casi diariamente, a visitar a la familia de Alan. Naty los considera su familia también porque no tiene trato con gran parte de la suya, sólo con algunos pocos tíos y primos. A su padre - quien posee serios problemas con el alcohol elige no verlo porque sostiene que nunca se ha ocupado de ella, que no la crió. "Mi mamá sí se ocupó de mí. Yo viví con mi mamá hasta que falleció de Sida, ella era prostituta, mi papá la sacó de ahí”.

Me detengo, pues llegué a destino luego de repasar mentalmente las historias de vida de la pareja creyente. Bajo de la bicicleta y me incorporo para ingresar a su vivienda. Empujo con énfasis la puerta de rejas rojas oxidadas que da lugar a un largo pasillo pero aún así no alcanza para abrirla. Pruebo nuevamente ejerciendo mayor fuerza, ahora sí. Entro, con el espacio justo y necesario para mi cuerpo y la bicicleta. Apenas alcanzo a cerrar la reja cuando me sorprenden los ladridos de perros, no sé si son dos o tres. De igual manera continúo y transito por el largo pasillo angosto. Observo 
que son tres, se acercan, huelen mis extremidades y continúan ladrando hasta que una mujer, Naty, al grito de: "Fuera ustedes, dejen de gritar", les ordena que se tranquilicen. "Pasá... entrá la bici. Vamos a tomar unos mates".

El pasillo desemboca en un patiecito de cemento - no en su totalidad - con un espacio de tierra para un árbol, bastante alto, que en verano, da sombra. En un rincón cerca del árbol hay una parrilla y un disco, también una mesa, sillas y piezas de juguetes de la niña distribuidos en el lugar. Del lado derecho de la vivienda ocupando el largo de la misma hay más piso de tierra, un rectángulo cerrado por alambre enrejado. Anteriormente allí la pareja tenía gallinas; ahora, sólo hay tierra. El frente de la vivienda no se extiende en ancho, es más bien pequeño. La pared es rústica con la textura y tonalidad del revoque grueso. Las aberturas son verdes, la ventana de postigos y con rejas; la puerta, de chapa. Al ingresar a la vivienda, nos topamos con la cocina y lo primero que capta nuestra atención es el santuario, imponente contra la pared ocupando casi la totalidad de la misma. La cocina es cuadrada, en un costado la mesada, antigua, con diversas roturas al igual que la pared que presenta abundantes manchas de humedad, y debajo de la mesada se entrevén artículos de cocina a través de unas cortinas azules un poco transparentadas por los años. Al lado de la cocina y enfrente, una mesa de madera rectangular y 4 sillas. En la pared de enfrente, un modular. Las paredes presentan decoraciones de fotos, dibujos de Azul y arte en Origami realizado por Alan. No obstante la atención se la lleva el santuario doméstico impactante por su dimensión.

En el santuario predomina el rojo, color representativo de la creencia en el Gauchito Gil. Su estructura es mayoritariamente de madera donde yacen todo tipo de ofrendas. Flores artesanales y naturales, velas, encendedores varios, cigarrillos, armas de juguete, estampitas, cuatro estatuas del Gauchito Gil, banderas, cigarrillos de marihuana, juguetes de la niña, botellas, una estatuilla de la virgen de Luján, 20 dólares, varios fajos de billetes de $\$ 2$ agrupados de a diez, balas, fotos de ellos, adornos del Gauchito Gil con luces, una foto de una ecografía de Azul, cuchillos, banderas del santo por detrás y en los costados, bebidas alcohólicas, pipas, mates, yerba con el nombre del Gauchito Gil, entre otras cosas. La encargada de "cuidarlo" y mantenerlo es Naty, quien menciona limpiarlo y tenerlo ordenado a modo de ofrenda y agasajo. 
Las conversaciones con Naty en su mayoría tienen relación con la maternidad. No falta oportunidad en que se refiera a su hija con halagos, resaltando sus cualidades y virtudes. "No puede ser tan buena ella ... es una santa", ejemplos como éste abundan.

\section{La gente "decente, digna y laburante" vs. los "pibes chorros"}

Comenzamos a notar que los creyentes realizan una ardua tarea de distinción y diferenciación. Se disputan la "dignidad" y "autenticidad" de culto en los espacios públicos sagrados.

Los adultos 15 del primer santuario dan a conocer la existencia de otros santuarios - para ellos "secundarios" - donde la práctica del culto al Gauchito Gil es defenestrada.

Los de aquel santuario van ahí para hacer mala junta, chupar, drogarse. Ni se sabe si van porque creen" "nosotros venimos a compartir en familia y con el gaucho. Somos gente decente, no chorros.

Construyen una identidad diferenciándose de lo que no quieren ser. "Nosotros somos creyentes creyentes. Prometemos, cumplimos y somos gente de bien, hacemos lo que al gaucho le gustaría”. Los jóvenes, en cambio, en muchas ocasiones prefieren no hablar siquiera de su práctica de culto, y en otras expresan su disgusto por el culto de "los decentes".

"No sé, no me cabe, qué se yo, no voy nunca a ese". "Es corte más careta ese, yo ni voy". "Yo corte que siempre pido en el santuario de mi casa, a veces vamos al de Sierra, porque viste este que está cerca, ahí en la ruta, van algunos viejos re ortivas, corte que te miran medio mal y ni da" (Joven, trabajador ilegal, 20 años).

La distinción que realizan los fieles revela prácticas simbólicas y la fragmentación entre diversos sectores. La identidad se construye a partir de la oposición con un "otro", a la vez que cuando es necesario, la identidad de creyentes es homogeneizada como un "nosotros". Dependiendo del contexto, las maneras de construir y expresar la identidad, mutan. Esto se vincula con lo que sostiene Silvia Boggi (refiriéndose al objeto de su investigación): los

\footnotetext{
${ }^{15}$ Decidimos generalizar a los creyentes "decentes" en esta categoría ya que en su mayoría son actores sociales adultos y mayores en contraposición a los jóvenes del otro oratorio "rutero".
} 
Imaginarios que operan como mediadores de las instancias estructurales, penetran e impregnan las imágenes que los grupos pentecostales construyen acerca de sí mismos, provocando que en el juego comunicativo de enunciar un "nosotros" se oscile entre el mostrar hacia afuera de los grupos una imagen "unitaria" y la reproducción del estigma generado externamente que fragmenta al movimiento pentecostal y lo transforma en espejos astillados (Boggi, 2007: 14).

"Mirá [mientras me muestra una estampita del Gauchito Gil guardada en su billetera] si los ratis te ven con esto te hacen causa de pibe chorro", esta imagen que poseen de sí mísmos.

Es un reflejo de los imaginarios sociales que los descalifican y producto también de la disputa por un espacio social y simbólico que refuerza y reproduce las marcas negativas que socialmente pasan sobre ellos (Boggi, 2007: 9).

Al igual que los pentecostales, sucede con quienes rinden culto al Gauchito Gil que estas marcas simbólicas negativas y negativizantes, se ven reflejadas en los medios de comunicación, "en cómo construyen significado en torno a ellos, como son convertidos en noticia y también en las imágenes que desde el sentido común se edifican" (Boggi, 2007: 14). En ambos casos existe tendencia a estigmatizarlos y convertirlos en secta o en una religión "de segunda".

Resulta significativo señalar que los fieles de este último santuario, al cual el imaginario hegemónico descalifica como "los pibes chorros", se autoadscriben como creyentes del Gauchito Gil sin necesidad de invocar denominando su santuario. Lo público aparece como invocación con motivo de reivincicación. Cuando se afirma una identidad de esta manera, indica que está en resistencia porque existe riesgo de pérdida. La marca de los imaginarios hegemónicos que estigmatizan a los "pobres urbanos" recae en los "decentes" quienes construyen estructuralmente mecanismos de legitimación de su culto y creencia que sugiere que no deberían creer, en tanto sus valores y cotidianeidad no serían características de quienes son o deben ser creyentes.

Estas identidades estigmatizadas son una construcción social desde la otredad que también es asumida por el nosotros, una identidad apropiada por los vecinos de los barrios mancha y resignificada a través de diversas estrategias (Leiro, 2005: 110).

El quiebre o no integración de la imagem de una ciudad desigual consigue romper con la propia noción "acrisolada" que construyen los creyentes del Gauchito Gil. 
Al analizar esta distinción nativa entre "los decentes" (que ponen en marcha mecanismos de legitimación para validar y mantener su creencia) y "los chorros" (que serían los destinatarios indicados de los cultos tanto para la ciudad de Olavarría como para ellos mismos) desde una mirada que contemple la totalidad en la cual permanecen inmersos esos grupos, podemos entender la aparente paradoja - de asumir un "nosotros" en ocasiones y diferenciarse en otras.

\section{Recurrencias empíricas y pobreza estructural}

Estos templos urbanos donde se rinde culto al Gauchito Gil muestran las siguientes diferencias. El santuario de la "gente decente" construye su identidad en contraposición a "los chorros del otro santuario". Las ofrendas otorgadas en uno y otro difieren. En el primero resulta correcto donar al santo elementos que sean de su agrado, por ejemplo consumos que Antonio Gil poseía en su vida. Las ofrendas y los valores deben ser "como la gente" y responder a una moral hegemónica, que contemple aspectos de un "verdadero" o "auténtico" creyente a la vez que ciudadano decente. En este caso, se deberá ofrendar vino, ya que Gil consumía, quizá también algún cigarrillo, muchas velas, estatuillas del catolicismo, fotos, banderas, cartas, entre otras, quedando por fuera ofrendas singulares de los demás santuarios que representan -para estos fieles “decentes"- la ilegalidad, los no creyentes "verdaderos, la "mala junta" y "mala gente", lo indeseable. Estos otros santuarios que podríamos homogeneizar como de los "jóvenes", tienen similitudes en cuanto a los tipos de ofrendas. Abundan tetrapacks de vino de bajo costo - mientras que en el anterior hay botellas -, también los cigarrillos de marcas más económicas, las "tucas" de marihuana, dinero en billetes menores, balas, armas de juguete y armas reales.

Lo sagrado o lo sacralizante en cada uno de los santuarios cobra un aspecto diferente. En el santuario "decente" se sacraliza la socialización entre actores sociales de sectores medios que poseen afinidad por compartir otras actividades, además de acudir a ese espacio. Lo sagrado puede simbolizar el mantenimiento de cierta moral religiosa ligada al catolicismo y a los valores de "la gente" como trabajar con voluntad y esfuerzo para conseguir lo que se tiene ya que es necesario "ganárselo" y no que "alguien te lo regale". En el santuario de los "pibes chorros", cercano a Sierra Chica, también lo sagrado podría ser la socialización pero de otro tipo, entre jóvenes que 
permanecen ocultos ya que la fisonomía del lugar lo permite - detrás de paredes de roca -. Lo sagrado son ellos, "la ranchada", al igual que sucede en el templo barrial de la esquina del barrio periférico. La "barrita del barrio" es lo sagrado, sus prácticas cotidianas y diarias. Mientras que en el santuario "doméstico" o privado sucede algo diferente. Lo sagrado allí no se relaciona tanto con el gran altar en la cocina o con "la ranchada" de Alan. Sino que lo sagrado para Naty es Azul. Ella, en tanto ama de casa, transcurre la mayor parte del día en su hogar realizando tareas de limpieza y cuidado de su niña mientras por la madrugada le reza al santo para que su pareja regrese sin tener ningún inconveniente con la policía o alguna "barrita" enemiga. Endiosa a su hija porque Naty manifiesta que es "todo lo que tiene", "es una santa, no puede ser tan buena".

También podemos vincular lo "legal" con la visibilización de los cultos. En las rutas mayoritariamente las ofrendas son de carácter más "decente". Formarían parte de lo que se puede y quiere ser mostrado. Mientras que en los espacios más ocultos como es al interior del barrio y del oikos, las ofrendas tienen que ver con la ilegalidad urbana.

Ahora bien, vimos las divergencias, pero existen recurrencias empíricas que tienen que ver con el plano estructural que hacen que exista diversidad de santuarios o "producción simbólica" de templos urbanos. Los espacios urbanos en los cuales se sitúan estos cultos serían habitados y característicos -para el imaginario hegemónico- de gente "mala" y "delincuente", que, en concordancia con la teoría de la marginalidad urbana, "poseerían rasgos constitutivos típicos de por sí, que los separan del resto de la sociedad" (Gravano, 2015: 93). Visto de esta manera, los creyentes permanecen en situación de precariedad urbana porque, o no se han adaptado a la vida moderna o no realizan el "esfuerzo" individual por superarse y obtener una vivienda, un trabajo estable, entre otras cuestiones. En cambio,

Los pobres urbanos constituyen los sectores subalternos de la ciudad. Pertenecen a la 'periferia' del sistema urbano en cuanto al consumo de éste. Y son producto de una construcción social que los segrega y estigmatiza. Como dice Rosana Guber, la segregación se manifiesta no sólo en el aspecto urbano sino en lo social, lo ideológico y lo jurídico [...] La pobreza urbana, como emergente de la estructura social, es el problema central dentro del cual la marginalidad constituye un modo de verla y valorarla (Gravano, 2015: 87). 
Podemos ver que existe una relación entre las recurrencias estructurales de los santuarios y la pobreza estructural urbana expresada, podríamos afirmar, en diferentes momentos de la vida de los fieles. Podríamos decir que los sectores medios han conseguido posicionarse actualmente de diferente manera a cuando eran jóvenes. Muchos poseen vivienda propia y trabajo estable luego de haber pasado por una juventud similar a la de "los pibes chorros". Los "delincuentes", serían el resultado de sistemáticas crisis, más profundas y amplias que la de los últimos veinte años, en cambio los "decentes" quizá no han atravesado tanta cantidad de crisis estructurales y han podido en diferentes momentos generar mejores recursos para tener una posición diferente a los "pibes chorros" (trabajo estable y vivienda propia).

Estos santuarios son templos modernos con una especificidad en la ciudad media. Lo histórico-estructural se manifiesta en la escala media con cierta especificidad que intentamos mostrar. Existen templos hegemónicos como los del cristianismo y otros, como es el caso, no pertenecientes a una práctica instituída. Como podemos ver en lo que expresa Boggi, existe una imagen homogeneizadora que manifiesta la idea de que en esta ciudad "somos todos católicos". Por el contrario, la práctica del protestantismo es concurrida y podría tomar el carácter de contra-hegemónica, al igual que los santuarios del Gauchito Gil.

Estas expresiones materiales de la religiosidad popular - espacios de culto predominan, como intentamos mostrar, en vías de acceso a la ciudad y al interior de "barrios mancha" (Gravano, 2013). Los imaginarios de los distintos segmentos sociales de la ciudad media se contextualizan necesariamente en el espacio urbano heterogéneo pero no sólo como indicador de desigualdades sino como constitutivo de lo urbano. Los imaginarios urbanos de la ciudad - reconvertidos debido a los resultados que dejó la crisis de los años 90 y 2001-, la condensan como la habitada por "los del conurbano". A partir de la llegada de ese "otro peligroso", Olavarría dejaba de "crecer para arriba" para expandirse hacia "los costados" diferenciados de "adelantes" y "centro" (Gravano, 2013). Estos "atrases" conformarán los barrios "mancha” o "lunares' urbanos que sirven de chivos expiatorios de los problemas que hoy atraviesa la ciudad, principalmente el de la inseguridad" (Gravano, 2005: 49). Aunque empíricamente realicen un esfuerzo por diferenciarse ambos grupos religiosos estructuralmente son los necesarios para hacer la ciudad, son trabajadores que acceden a la ciudad media, pero a medias. 
Estos templos urbanos no hegemónicos de sectores segregados de los consumos y servicios de la ciudad, aceitan esas desigualdades estructurales, y es por ello que la función que cumplen es estructural. Para los fieles éste sería de gran ayuda para garantizarle a la familia que no le falte nada. La adhesión al santo les permite vivir la ciudad a pesar de las condiciones materiales precarizadas y de explotación. Por ello estos templos, a diferencia de otros hegemónicos como los del catolicismo, pertenecen a sectores populares que son los que contribuyen a la producción de la ciudad pero que no pueden consumirla como otros sectores. Históricamente, los templos, como sostiene Lewis Mumford (Gravano, 2015: 58) han pertenecido a los sectores "ociosos" de la ciudad, los que no se encargaban de producirla. En este caso, como hemos intentado demostrar, sucede lo contrario. Sirven para sobrellevar las desigualdades sociales, como exhibe Rubén Dri al caracterizar al culto popular como

Símbolo de resistencia popular al modelo de pobreza y destrucción vigentes [...] tendiente a remover las causas de la opresión de todo un pueblo [...] Como tantos otros cultos populares, con sus contradicciones, resguarda la utopía de los sectores históricamente golpeados, humillados y derrotados (Dri, 2003: 119).

Pero también, en concordancia con el enfoque dialéctico, podríamos analizarlo en tanto impedimento para lograr tomar conciencia de la situación de explotación en la cual están insertos.

\section{Consideraciones finales}

Se intentó mostrar la heterogeneidad de templos del santo popular que tensionan la idea de homogeneidad dentro de la ciudad media. Se comenzó con un interrogante empírico y de sentido común sobre por qué existe diversidad de un mismo culto en esa heterogeneidad urbano-espacial, intentando responder de manera tanto empírica como teórica. Creemos necesario abordar la articulación de un análisis que contemple lo estructural y lo significacional de lo urbano, que evidencie - a través de la etnografía cómo inciden los procesos estructurales en los imaginarios urbanos en centros de rango medio. De esta manera, se intenta contradecir el flujo mítico hegemónico del crisol social de la ciudad media capitalista, exhibiendo que los sectores sociales no viven la ciudad de igual manera, sino que existe una fragmentación del valor de uso de la ciudad en articulación con las crisis estructurales que han impulsado el culto al Gauchito Gil. 
La etnografía nos lleva a exhibir esa no integración de imaginarios propia de los efectos de las crisis capitalistas que inciden en el contexto local. El mito del acrisolamiento se contrasta con los barrios "mancha" que albergan los templos urbanos populares, en el espacio público diverso y en el doméstico. La heterogeneidad socioespacial ligada a espacios de culto público, los valores disímiles que se esgrimen sobre el culto y lo que se considera sacralizante en cada santuario evidencian cómo el imaginario de la ciudad (en su especificidad media) juega un papel importante como condicionante de prácticas y representaciones. Los fieles no sólo viven en la ciudad media sino que la viven a través de la práctica de culto y creencia de un santo popular emergente de la crisis de los años 1995 y 2001. En este sentido, reafirmamos la importancia de utilizar herramientas metodológicas del enfoque antropológico para no confundir que lo que la gente dice es efectivamente lo que hace y realizar así un análisis más profundo. La perspectiva antropológica y cualitativa se enriquece en el uso del registro y análisis de las representaciones, imaginarios y vivencias de los actores, junto a las condiciones materiales de su reproducción social en estructuras y sistemas. De esta manera, intentamos reflejar la heterogeneidad religiosa articulada con la urbana, aún en un mismo culto, que es contrastado empíricamente en tanto existe una producción simbólica de santuarios heterogéneos, a la vez que, en el plano estructural, podemos -de cierta manera- resaltar lo que puedan tener en común.

\section{Referencias}

BAJTIN, Mijail. La cultura popular en la Edad Media y el Renacimiento. Buenos Aires, Alianza, 2003.

BOGGI, Silvia. Cualquiera es un pastor, cualquiera es un ladrón. En: Gravano, Ariel (compilador) Imaginarios sociales de la ciudad media. Tandil, REUN; pp. 51-68, 2005. BOGGI, Silvia. Espejos Astillados: La Construcción de la Identidad Pentecostal en la Ciudad de Olavarría. Olavaría, UNICEN, 2007.

CARROZZI, María J. Nuevas perspectivas en el estudio de canonizaciones populares en América Latina. Ponencia presentada en el VII congreso Argentino de Antropología Social, Villa Giardino, 2004.

CARROZZI, María J. Antiguos Difuntos y Difuntos Nuevos Las Canonizaciones Populares en la década del 90. En: en Daniel Miguez y Pablo Semán (Eds.), Entre Santos cumbias y Piquetes. Las Culturas Populares en la Argentina Reciente, Buenos Aires, Biblos, 2006.

CASTORIADIS, Cornelius. La institución imaginaria de la sociedad. Buenos Aires, Tus Quets, 1993. 
GALARZA, Bárbara. Apuntes sobre las etnografías del urbanismo: La producción teórico-metodológica de la Escuela de Chicago. En: A. Gravano. (Ed) Antropología de lo urbano. 2da edición (pp. 247-262). Buenos Aires, Café de las Ciudades, 2015.

GARCIA CANCLINI, Nestor. Las Culturas Populares en el Capitalismo. México DF, Nueva Imagen, 1986.

GRAVANO, Ariel. Antropología de lo barrial: estudios sobre producción simbólica de la vida urbana. Buenos Aires, Espacio, 2003.

GRAVANO, Ariel. La ciudad manchada. En: Gravano, Ariel (compilador) Imaginarios sociales de la ciudad media. Tandil, REUN;pp. 81-101, 2005.

GRAVANO, Ariel. Antropología de lo urbano. Tandil, UNICEN, 2013.

GRAVANO, Ariel. Antropología de lo urbano. Buenos Aires, Café de las ciudades, 2015.

GRAVANO, Ariel. (Comp.) Imaginarios sociales de la ciudad media. Emblemas, fragmentaciones y otredades urbanas. Estudios de Antropología Urbana. Buenos Aires, Universidad Nacional del Centro, 2005.

GUBER, Rosana. Villeros, o cuando querer no es poder. En: A. Gravano. (Ed) Antropología de lo urbano (pp. 263-310). Tandil, Universidad del Centro, 2015.

HARVEY, David. Urbanismo y desigualdad social. Madrid, España, Siglo XXI, 1977. HOBSBAWN, Eric. Rebeldes primitivos. Barcelona, Ariel, 1983 (1968).

LEIRO, María C. Esto no es una ciudá, la meta imagen mediática como referente. En: Gravano, Ariel (compilador) Imaginarios sociales de la ciudad media. Tandil, REUN; pp. 69-77, 2005.

LEIRO, María C. Mi cárcel y mi libertad, o la circulación del miedo en Olavarría. En: Gravano, Ariel (compilador) Imaginarios sociales de la ciudad media. Tandil, REUN; pp. 103-113, 2005.

LINS RIBEIRO, Gustavo. Descotidianizar. Extrañamiento y conciencia práctica, un ensayo sobre la perspectiva antropológica. En: Boivin, M.; Rosato, A.; Arribas, V. (2004) Constructores de otredad. Antropofagia, Buenos Aires; pp. 194-198, 2004. LYNCH, Kevin. La imagen de la ciudad. Buenos Aires, Infinito, 1966.

MÍGUEZ, Daniel; SEMÁN, Pablo. Entre santos, cumbias y piquetes: Las culturas populares en la Argentina Reciente. Biblios, Buenos Aires, 2006. MÍGUEZ, Daniel. Delito y cultura. Los códigos de la ilegalidad en la juventud marginal urbana. Biblios, Buenos Aires, 2008. MONREAL, Pilar. Ciudades neoliberales: ¿el fin del espacio público? Revista Quaderns-e. Volumen (21) pp. 98-112, 2016. MONS, Alain. La metáfora social, imagen, territorio, comunicación. Buenos Aires, Nueva visión, 1992.

SILVA, Ana. y BOGGI, Silvia. Estudios sobre imaginarios de ciudades medias. En: Gravano, Ariel; Silva, Ana y Boggi, Silvia (editores): Ciudades vividas: sistemas e imaginarios de ciudades medias bonaerenses. Buenos Aires, Editorial Café de las Ciudades; (ISBN 978-987-3627-11-8; en prensa), 2016.

SÉMAN, Pablo. Cosmológica, holista y relacional: una corriente de la religiosidad popular contemporánea. Ciencias Sociales y Religión/Ciências Sociais e Religião, 3, pp. 45-73, 2001.

Recebido em: 21/09/2017. Aprovado em: 15/11/2017. 